\title{
PENGENALAN DAN PELATIHAN PROGRAM MICROSOFT WORD DI SEKOLAH MENEGAH PERTAMA PGRI KOTA BENGKULU
}

\author{
Faking toro*1, Salamun ${ }^{2}$, Hermawansa $^{3}$ \\ Rekayasa SistemKomputer, UniversitasDehasen, Bengkulu \\ Email:*fakingtoro@gmail.com
}

\begin{abstract}
ABSTRAK
Perkembangan teknologi sekarang ini, khususnya teknologi komputer sudah sangat maju. Termasuk di indonesia sudah banyak produkproduk komputer yang dipasarkan dengan beragam jenis, harga dan spesifikasi. Industri pembuatan komponen Hardware komputerpun saling basaing dalam memuaskan para komsumen maupun pelanggannya. Untuk menyikapi hal tersebut maka kita sebagai konsumen sebaiknya berhati-hati dalam memilih dan membeli komponen hardware tersebut. Dalam penggunaannya computer sudah digunakan disegala bidang. Salah satunya penggunaan Microsoft Word.Dalam pengabdian ini, dilakukan pelatihan program Microsoft Word KepadaSiswa SMP PGRI Kota Bengkulu.
\end{abstract}

Kata Kunci:Microsoft Word, SMP NegeriPGRI Bengkulu

\section{PENDAHULUAN}

Perkembangan teknolog sekarang ini, khususnya teknologi computer sudah sangat maju dan semakin modern. Pada tahun 1981, Microsoft menyewa Charles Simonyi, pengembang utama Bravo, prosesor GUI kata pertama, yang dikembangkan di Xerox PARC. Microsoft Word dirancang untuk digunakan dengan mouse, dan mampu menampilkan beberapa format, sepertitebal, miring, danbergarisbawahteks, walaupun tidak bisa membuat font. Pada tahun 1985, Microsoft Word porting ke Macintosh. Ini dibuat lebih mudah oleh kenyataan bahwa Firman untuk DOS telah dirancang untuk digunakan dengan tampilan resolusi tinggi dan printer laser, meskipun tidak ada yang belum tersedia untuk masyarakat umum.

Usaha pertama Microsoft untuk sinkronisasi nomor versi di seluruh platform. Word 3.0 termasuk berbagai perangkat tambahan internal danfitur baru, termasuk implementasi pertama dari spesifikasi Rich Text Format (RTF), namun terganggudengan bug. Microsoft Word untuk memanfaatkan popularitas Windows 'meningkat dengan merilis sebuah versi Word untuk DOS. Dan sampai sekarang ini word terus berkembang seiring dengan perkembangan zaman.Yang disatukan dalam Microsoft office sekarang ini.

Termasuk salah satunya dalam mendukung pengelolaan sekolah. Rencana Strategis Departemen Pendidikan Nasional, secara eksplisit menyebutkan tiga pilar kebijakan pendidikan nasional, yaitu: (1) perluasan dan pemerataan akses, (1) peningkatan mutu, relevansi dan daya saing, dan (3) penguatan tata kelola, akun tabilitas dan citra public pendidikan, untuk mewujudkanpendidikan yang bermutu, akuntabel, murah, merata dan terjangkau rakyat banyak 
(Community Service in the Field of Science, Technology, and Agricultural)

Available online at : http://journal.pdmbengkulu.org/index.php/padamunegeri DOI: DOI: https://doi.org/10.37638/PadamuNegeri.1.1.21-25

Perluasan dan pemerataan akses pendidikan, diprioritaskan sebagai media pembelajaran jarak jauh. Sedangkan untuk pilar kedua, peningkatan mutu, relevansi dan daya saing, peran TIK diprioritaskan untuk penerapan Dalam pendidikan/proses pembelajaran. Terakhir, untuk penguatan tata kelola, akun tabilitas dan citra public.

\section{METODE}

Berikut Proses Kegiatan Pengabdian Masyarakat yang telah dilaksanakan yaitu dapat dilihat pada table 1 .

Tabel 1. Proses KegiatanPengabdianMasyarakat

\begin{tabular}{|c|c|c|c|}
\hline Hari/Tanggal & Pukul & Kegiatan & \\
\hline \multirow[t]{7}{*}{$\begin{array}{l}\text { Senin, } 19 \text { Desember } \\
2016\end{array}$} & $08: 30-09: 00$ & $\begin{array}{l}\text { Persiapan berupa } \\
\text { perlengkapan, } \\
\text { proses pembagian } \\
\text { softcopy } \\
\text { bahan seminar dan } \\
\text { laptop untukasing- } \\
\text { masing kelompok. }\end{array}$ & \\
\hline & $09: 00-09: 30$ & $\begin{array}{lr}\text { Pembukaan } & \text { acara } \\
\text { dan } & \text { kata } \\
\text { sambuatan } & \text { Oleh } \\
\text { kepalah } & \text { sekolah } \\
\text { SMP PGRI Kota } & \text { Bengkulu. }\end{array}$ & \\
\hline & $09: 30-10: 30$ & $\begin{array}{l}\text { Seminar } \\
\text { Pengenalan dan } \\
\text { Pelatiahan } \\
\text { Microsoft word. }\end{array}$ & \\
\hline & $10: 30-10: 15$ & $\begin{array}{l}\text { Latihan } \\
\text { pengetiakan }\end{array}$ & \\
\hline & $10: 15-10: 30$ & Uji cobah soal & \\
\hline & $10: 30-11: 00$ & Lanjut Kuis & \\
\hline & $11: 00$ & Penutup & \\
\hline
\end{tabular}

\section{HASIL DAN PEMBAHASAN}

\section{Hasil Aktivitas}

A. Memulai Program Microsoft Word

1. Pilih tombol Start di pojok kiri bawah tampilan windows.

2. Setelah muncul tampilan menunya pilih Program, kemudian Microsoft Office dan Pilih

3. Microsoft Office Word 2007

4. Muncul Gambar berikut 


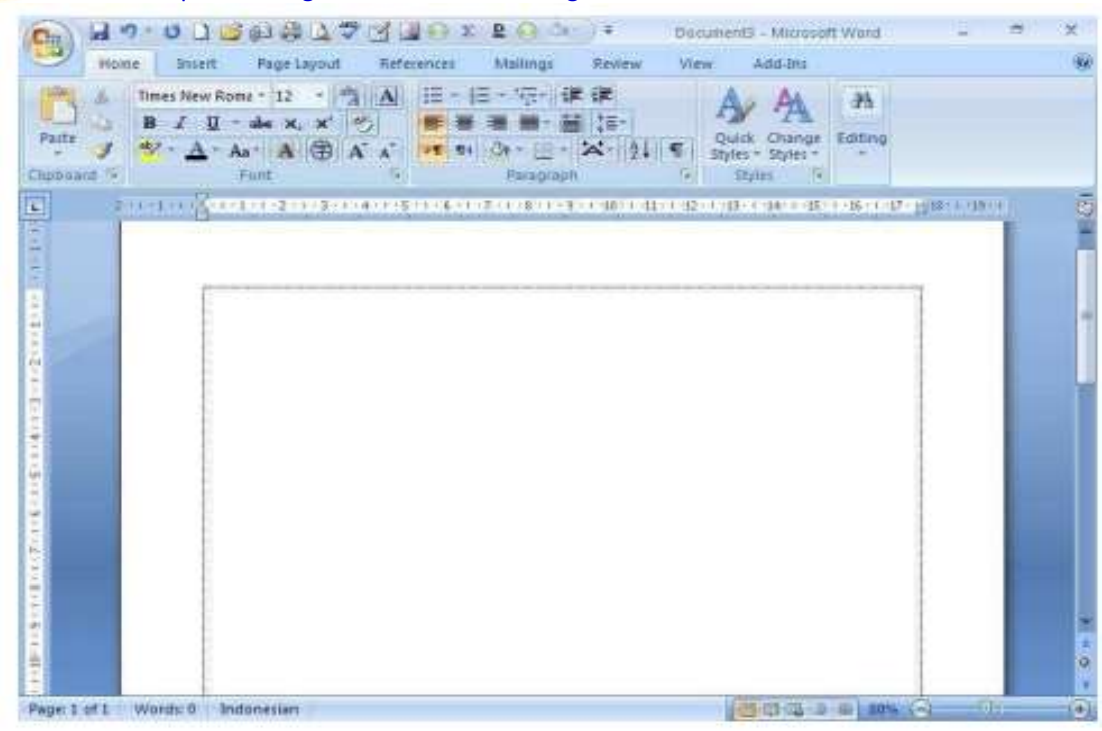

\section{Gambar 1.Tampilan Microsoft Word}

Keterangan :

a. Office Button

- Membuat file baru

- Membuka file

- Menyimpan file

- Mencetak

- Keluar dari word

Disebelah kanan office button terdapat button yang digunaka untuk menyimpan, Undo, Redo dan Customize Quick Access Toolbar

b. Customize Quick Access Toolbar

Digunakan untuk menampilkan button2 yang diinginkan untuk tampil pada taskbar, sebagai contoh jika kita klik button open dan new document, akan muncul button tersebut pada taskbar sebagai tips, tampilkan button yang sering anda gunakan untuk mempercepat pengerjaan.

c. Menu

Pada Ms Word 2007 ditunjukkan pada gambar berikut Setiap menu yang aktif (yang kita Klik) akan memunculkan toolbar dibawahnya.

1. Toolbar

Merupakan deretan tool-tool (gambar-gambar yang berbentuk tombol yang mewakili perintah dan berfungsi untuk mempermudah dan mengefisien kapengoperasian program

2. Kursor

Kursor atau Insertion Point merupakan indicator tempat dimana teks akan muncul jika kita akan mengetik. Posisi ini perlu diperhatikan karena Ms Word menggunakannya sebagai dasar dalam melakukan suatu pekerjaan yang kita perintahkan.

3. PenggulungTeks

Untuk memudahkan dalam membaca suatu dokumen dengan menggulung layar vertical dan horizontal.

4. MemasukkanTeks 
(Community Service in the Field of Science, Technology, and Agricultural)

Available online at : http://journal.pdmbengkulu.org/index.php/padamunegeri

DOI: DOI: https://doi.org/10.37638/PadamuNegeri.1.1.21-25

Setelah mengenal dasar-dasar layar Word, teks dapat langsung dimasukkan.

Ada beberapa hal yang perlu diketahui:

- Tab digunakan untuk mengidentasi pada baris pertama.

- Word secaraotomatis akan memulai baris baru sewaktu teks mencapai tepikanan halaman.

- Apabila terjadi kesalahan mengetik tekan Backspace untuk menghapusnya.

- Tekan enter untuk menambah baris kosong.

- Titik Sisip (kursor) Digunakan untuk memulai memasuk kanteks.

- Penunjuk Mouse bergerak dilayar sewaktu mouse digerakkan. Penunjuk ini tampak dalam bentuk huruf I atau panah.

5. MemperbaikiTeks

Ketika suatu dokumen dibuat, seringkali perlu memindahkan titiksisi pun tuk menambah atau menghapusteks di lokasi yang berbeda. Caranya sebagai berikut :

6. Menggunakan Mouse

Geser pointer mouse yang berbentuk I-beam keposisi yang anda kehendaki pada area teks dan klik mouse. Jika posisi yang anda tuju tidak tampak, perlu menggulung kelokasi yang diinginkan, gunakan panah atas dan bawah untuk naik atau turun satu baris. Gunakan panah double atas dan bawah (dibawah toolbar vertical) untuk naik atau turun satu halaman.

7. Menggunakan Keyboard

Jikaandamenggunakantombolpada numeric keypad, p astikanbahwa NUM LOCK dalamkeadaan off.

8. Menyimpan Dokumen

Untuk menyimpan dokumen klik office button kemudian pilih Save atau klik button pada Toolbar.

9. Menutup Dokumen

Bila sudah selesai mengerjakan suatu dokumen dan sudah selesai menyimpannya, mungkin perlu menutup dokumen dan setelah itu mengerjakan dokumen lain. Klik office button dan pilih Close.

10. Membuka Dokumen

Untuk membuka dokumen klik office button dan pilih Open, Word akan menampilkan dialog box berikut:

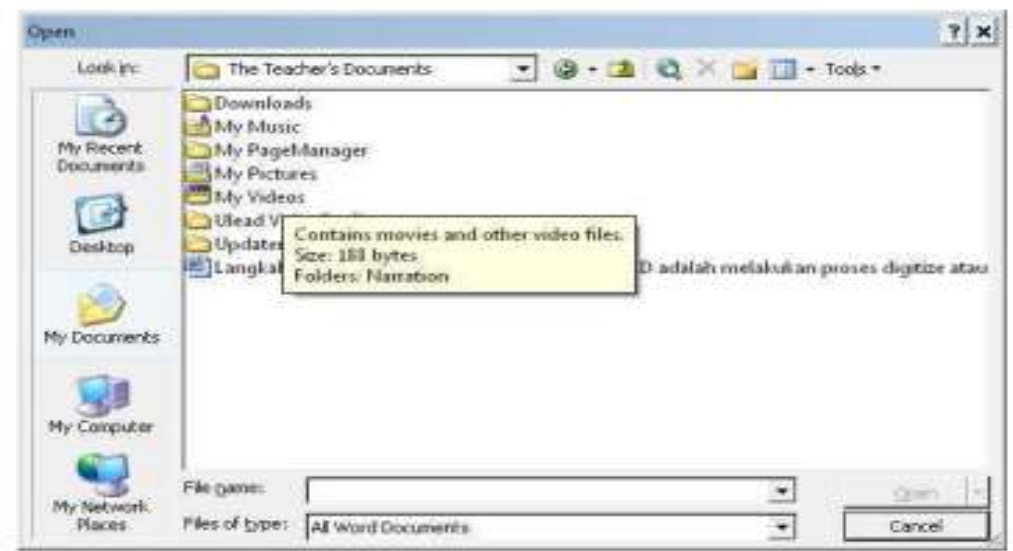

Carilahdirectorydan Folder Yang menampung file yang akan dibuka pada bagian Look in lalu klik file yang akan dibuka kemudian tekan button Open maka file anda akan ditampilkan dilayar Word. Sebagai latihan, bukalah

kembali file Lat1.doc yang sudah dibuat tadi.

11. Keluar dari Word 
(Community Service in the Field of Science, Technology, and Agricultural)

Available online at : http://journal.pdmbengkulu.org/index.php/padamunegeri DOI: DOI: https://doi.org/10.37638/PadamuNegeri.1.1.21-25

Click tombol yang ada di pojok kanan atas window Word maka aplikasi word akan hilang.

Penyelesaian Masalah

Bagian ini menjelaskan bagaimana hasil aktivitas pengabdian dapat menyelesaikan permasalahan masyarakat dengan mengungkapkan indikatornya, kekuatan internal, dan kesempatan eksternal yang membantu aktivitas penyelesaian masalah, serta kelemahan internal dan hambatan eksternal yang mengganggu aktivitas pengabdian.

\section{KESIMPULAN DAN SARAN}

A. Kesimpulan

1. Komputer sangat penting didalam kehidupan sehari-hari karena komputer sebagai alat bantu dalam mengerjakan peketjaan kan tor maupun tugas kulia dan sekolah.

2. Parah peserta pelatihan mampu mengetahui dan memahami toolf-toolf yang terdapat dalam aplikasi Microsoft word, sehingga mampu mengoprasikan Microsoft word.

3. Para peserta dapat melakukan pengetika dan sesuia dengan ketentuan Bahasa yang baik dan benar.

B. Saran

1. Perlu pelaksanaan yang labih konkrit dalam melakukan pelaksanaan pengabdian

2. Perlu pelatihan dan pengenalan yang lebih lanjut untuk untuk menambah pengetahuan para peserta dalam pelatihan pengenalan Microsoft word.

3. Diperlukan implementasi pengembangan dari pelatian pengenalan microsft word di SMP PGRI Kota Bengkulu.

\section{DAFTAR PUSTAKA}

Andi.(2014). Buku Panduan Lengkap Microsoft Word 2000.

Buku, Plain dan Simple, Microsoft Word 2010. Microsoft Press 2010

Farhan Aziz Lubis.Jurnal Pengertian Microsoft Word. 